\title{
Recommendations and Thermal Insulation for Desert Countries
}

\author{
Naje Mohamed Abdulla ${ }^{1}$, Ervin Lumnitzer ${ }^{2 *}$ \\ 1,2 Technical university of Košice, Faculty of Mechanical Engineering, Department of Environmental Studies and Process Control
}

\begin{abstract}
BIOGRAPHICAL NOTES
Ervin Lumnitzer, prof. Ing. PhD. He is graduated at Technical University of Košice in the field of "Robototechniques" in 1985. In 1995 he defended his dissertation thesis in field of "Mechanical Technologies" and in 2002 habilitated in the field of "Automation and Control". Nowadays he works as a university teacher. He is the head of the Environmental Engineering Department, authorized person for noise measurements in living and working environment, referee of bachelor stud ies in field of Environmental Management, chairman and also member of board of state examiners. Lately he is focused on the field of noise measurements and assessment, protection against industrial noise, noise mapping, noise visualization, assessment of the working environment quality.
\end{abstract}

\section{KEYWORDS}

Libya, thermal insulation, desert, weather conditions.

\begin{abstract}
This paper focuses on the analysis of the weather conditions during the day and at night in the dessert areas in Libya, the way they influence the inhabitants' thermal comfort, the causes of their impact on the constructions of the houses, and possible thermal-insulation methods that could be employed in order to prevent extremely hot air from infiltrating into the rooms, that are constantly air-conditioned, and increase the inside room temperatures, as well as try to describe and choose suitable thermal-insulation materials in order to decrease the air-conditioning devices needs which will help decrease electricity costs for air-conditioning devices function.
\end{abstract}

\section{Introduction}

Within Libya five different climatic zones have been recognized, but the dominant climatic influences are Mediterranean and Saharan. These conditions complicate design of housing areas because of the extremely high temperatures during the day and low temperatures at night.

\section{Weather conditions in Libya}

The Mediterranean Sea and the desert affect Libya's climate. In the winter, the weather is cold with some rain on the coast and the desert temperature can drop to subfreezing at night. Less than 2 percent of the national territory receives enough rainfall for settled agriculture. [2]. The Libyan Desert is one of the harshest and most arid in the world, and decades can go by without rain in certain areas, but this harsh interior is tempered by the Mediterranean climate in the north. Summers are hot and dry, 
while winters are cooler with lower temperatures in the evening, and rainfall is minimal. The desert is more extreme; hot in the day and cold at night. Spring and autumn experience the Ghibli, a hot, dry and dusty desert wind that can last from a day to four days. It brings temperatures in the coastal areas up to $50^{\circ} \mathrm{C}$ during the day but more commonly are around $40^{\circ} \mathrm{C}$. The Sahara's temperatures range from 15 to $30^{\circ} \mathrm{C}$ during the day and from 5 to $20^{\circ} \mathrm{C}$ at night from October to April. Rainfall is most likely to appear in January or February and rarely lasts long $[1,2]$.

\section{Design of Building for Hot Desert Areas}

The underlying points that must be included in the design of building located in the hot desert area are to provide maximum shading of direct and reflected sun radiation in the hot season, to balance the extremes of summer and winter by movable parts, to provide ventilation by regulated air movement and small openings, to avoid large exposed exterior surfaces, to use reflective outer surfaces, to balance the extremes of day and night temperatures by adequate thermal storage mass, to reduce internal heat production and conduction gain in hot seasons, to promote evaporation and heat loss by radiation, to increase air circulation in humid maritime regions [3].

\subsection{Climate conditions in hot dry areas}

The climate of hot-dry zones is in general characterized by high temperatures $\left(40-50^{\circ} \mathrm{C}\right.$ in summer), with sharp variations in both diurnal (day / night) and seasonal (summer-/ winter) temperatures; and precipitation (rainfall, snow) which is irregular and unreliable. Cold winds and dust/ sandstorms prevail in winter. The solar radiation intensity is high and enhanced by the radiation reflected from the ground. The air humidity is low and this climate is generally healthier than those of warm-humid lands. Different climatic zones can be distinguished within desert regions according to their specific geographical characteristics. Particular conditions in maritime desert regions mean that the high humidity causes definite discomfort in summer. On the other hand, the humidity tends to reduce diurnal variations and moderate temperatures [3].

\subsection{Issues of designing buildings in hot dry areas}

At construction of building in very hot desert areas, designers must bear in mind that the buildings will have to resist to extreme summer and winter conditions changes as well as day and night conditions to achieve a well balanced indoor climate. Cooling and passive heating are needed inside the buildings to the large changes in temperatures during the day and at night. Protection against intense sun radiation, dust, sandstorms, and insects is needed too. In desert regions by sea, the high humidity level jeopardise buildings and people and protection against humidity requires more air circulation (ventilation) in the summer. It is difficult to design buildings for this climate [3].

\section{Types of Insulation Materials}

There is wide range of insulation materials from fibre materials to rigid foams to foils. Bulky materials resist conductive and convective heat flow to certain extent. Rigid foam boards trap air or another gas to resist conductive heat flow. Foils in radiant barriers and reflective insulation systems are particularly useful in cooling climates $[4,5]$.

For example, fibreglass is commonly used in blanket and loose-fill types of insulation and is also available as rigid boards and duct insulation. Fibreglass loose-fill insulation is made from molten glass that is spun or blown into fibres. Loose-fill insulation must be applied in either open-blow applications (such as attic spaces) or closed-cavity applications (such as those found inside walls or covered attic floors) $[4,5]$.

Mineral Wool refers to two types of insulation material, rock wool and slag wool. It is commonly available either as blanket (batts and rolls) or loose-fill insulation. On the market, a softer, batt-type mineral product is available. Its thermal resistance is approximately comparable with sprayed cellulose insulation or high-density fibreglass batts [5].

Cellulose insulation is a product that packs tightly into building cavities, inhibits airflow. Cellulose insulation material usually does not require any o moisture barriers and, when installed at proper densities, it cannot settle in a building cavity. Cellulose insulation is used as loose-fill in open attic installations and dense packed in building cavities such as walls and cathedral ceilings. In new buildings, cellulose can be either damp-sprayed or installed dry behind netting [5]. 
Natural fibre insulation materials include cotton, sheep's wool, straw and hemp. Cotton insulation consists of $85 \%$ recycled cotton and 15\% plastic fibres. However, cotton insulation costs about 15\% to $20 \%$ more than fibreglass batt insulation. There are lots of other insulation materials available on the market [5].

\section{Recommendations and Traditional Solutions of Desert Buildings to Deal with Dessert Weather Conditions}

In order to achieve the best possible solutions to create thermal comfort in houses, various studies imply that it is important for the designers to take into considerations local weather conditions, traditional materials and designs of houses. It is valid mostly for desert areas in which the best materials and designs of houses appeared to be their traditional materials and designs that have been used for centuries. And in which foreign constructions procedures and architectonic proposal are useless and ineffective [6].

For example, in many desert towns and cities, the houses are attached tightly to one another with alleys that look like tunnels. It allows the buildings to deal with changes of weather conditions from cold to hot. The main pedestrian alleys are relatively well lighted from spaced light wells to provide the city with natural lightening and ventilation. The zones of light and dark spaces create pressure zones that make the air move from high-pressure zones to low pressure zones [6].

In those, hot air is replaced by cooler and more humid air in the dark passages. Houses usually consist of entrance, first floor and roof floor. The roof floor consists mainly of the kitchen and fuel storage room that, in fact, discharges extra heat by cooking. This floor is also a precaution against fire since inhabitants are likely to notice fire and escape the house before the house is on fire. Insulation of the below floors from the cold nights is achieved. Construction materials contain clay, limestone, gypsum, palm wood and so on [6].

\section{Conclusions}

In this paper, weather conditions in desert areas of Libya, types of insulation materials and importance of implementation of tradition designs and materials are discussed in order for the designers to be able to design a building that would provide its residents with thermal comfort.

\section{References}

[1] World Travels. Libya Climate \& Weather, from http://www. wordtravels.com/Travelguide/Countries/Libya/Climate.

[2] World wide weather and climate information. Average weather and climate in Libya, from http://www.weatherand-climate.com/average-monthly-Rainfall-TemperatureSunshine-in-Libya.

[3] Gut, P., Ackernecht, D.. 1993. Climate Responsive Building Appropriate Building Construction in Tropical and Subtropical Regions. SKAT,Switzerland.

[4] U.S. Department of Energy. Types of insulation, from http:// energy.gov/energysaver/articles/types-insulation.

[5] U.S. Department of Energy. Insulation materials, from http:// energy.gov/energysaver/articles/insulation-materials.

[6] Al-Zubaidi, S., M.. 2002. The effiency of thermal performance of the desert buildings - The traditional house of Ghadames, Libya. Annual conference of the Canadian Society of Civil Engineering, 5 - 12 pages. 